\title{
Reply to Michael Mann
}

\author{
Anatol Lieven ${ }^{1}$ \\ Published online: 25 January 2016 \\ (C) Springer Science+Business Media New York 2016
}

First of all, let me repeat my profound admiration for the scale and achievement of Mann's work as a whole. Indeed, concerning certain issues - like his differing dates for the origins of the welfare state in Europe - the sheer scale of Mann's work allows him to say, in the words of Walt Whitman, "Do I contradict myself? Very well then, I contradict myself. I am large, I contain multitudes".

I am entirely sympathetic to Mann's cry that his series is long enough without including more material on India and so on. When it comes to the "leading edge" countries of Britain and the USA, to which he devotes most of his later volumes, there is no need to spend much time on a discussion of the role of kinship, for example (with the politically important exception of the southern states of the USA, which Mann hardly mentions).

However, it is worth reiterating that this series is entitled The Sources of Social Power, that its first volume is called A History of Power from the Beginning to AD 1760, that it begins with the origins of organised human societies and a range of ancient peoples, and that Mann extends his IEMP framework far back into history. In this wider context, the omission of kinship as a highly important source of power cannot possibly be seen as valid.

Concerning the modern world, Mann dismisses kinship as a mere feature of "primitive" societies. He would probably do better not to say that in India, which, in the estimation of its own elites at least, represents modern democracy in Asia. There, kinship has been central to democratic politics both in terms of kinship-based vote banks at the bottom and political dynasties at the top; insofar as dynastic politics have been eclipsed at the centre (though not in the states), this has been at the hands of another sort of force that Mann ignores or downplays, a highly culturally specific form of ideological nationalism embodied in Narendra Modi's BJP and RSS.

While Mann chooses largely to omit India, in his final volume, he does naturally devote considerable attention - and admiration - to China and its tremendous resurgence in recent decades. There is a mass of evidence to show that kinship ties, although weaker than in the past, continue to permeate Chinese society-including in the Communist Party and its leadership. Indeed, one key aspect of President Xi Jinping's struggle against corruption in

Anatol Lieven

ppl6@georgetown.edu 
the Communist Party appears to be an attempt to prevent the party from becoming a hereditary rather than a meritocratic elite. This is a struggle with deep precedents in Chinese history, and its outcome may be crucial to the future stability and longevity of the existing Chinese system.

Concerning the importance of political culture and ideology as a source of social powerthe central issue of our disagreement - the question of when nationalism became a truly powerful force in Europe is one on which we simply will agree to differ. When it comes to mass nationalism, I would just like to point out that nationalist parties with mass support were well established in much of Western and Central Europe by the later 1880s and that the immediate causes of the First World War itself were the ferocious mass nationalisms of the Balkan countries.

Of course, this does not mean that everyone in these societies was affected, or affected to the same degree, or even at the same time. There is no contradiction between stating that mass nationalism was already an important phenomenon in France during the Revolution and agreeing with Eugen Weber that it took another century for this to fully penetrate much of the French countryside. Nor is there any contradiction in stating both that nationalism in Italy was a vitally important force by the 1840 s and that most of the rural population was barely influenced by the Risorgimento of the time. For if one is speaking of "the sources of social power", it is not necessary that the masses be engaged in a nationalist struggle, only that they be indifferent, while elite nationalist forces capture first cultural and then political hegemony. (That was also my personal observation of the nationalist revolutions in some of the Soviet republics in the early 1990s.)

Focusing in on Mann's "leading edge", the USA, and the roles of political culture, ideology, and nationalism, I emphatically do not describe the different main strands of American nationalism to be clearly and constantly opposed. On the contrary, I explicitly speak of them coming together on occasions, at moments of heightened national, social, or cultural tension. I describe this synthesis of civic and quasi-ethnic nationalism as occurring under the Bush administration after 9/11 and as forming a key part of the foundations of the Tea Party. For his part, Mann has no serious explanation of the uniquely American cultural and ideological mixture represented by the Tea Party.

Mann speaks of American "exceptionalism" as if this still means "how the United States differs from other Western countries". Clearly, in the mouths both of Republican politicians and of Democrats like Hillary Clinton - and of their followers - this no longer has anything to do with an examination and analysis of the ways in which the USA and its traditions do or do not differ from those of other countries. It is purely an assertion that America is better than those countries and therefore has the right to dictate to them when necessary - an entirely nationalist position. This was never more apparent than in the ferocious attacks on President Obama when he said that he believes in American exceptionalism but that other nations also have their own exceptionalisms; he has since lost no opportunity to stress his own American exceptionalism.

Concerning the work on US political culture by famous American scholars on which my own work is chiefly based, Mann says simply that he rejects this intellectual tradition. This is not a serious position. If Mann had cited their works and shown-with evidence and arguments - why he disagrees with them, then this would have been a serious position with which one could have constructively disagreed. But it is not possible to credibly reject the role of religion as an historic source of power in America without engaging with Robert Bellah and his school, any more than it is possible to reject the idea of a deeply rooted US ideological nationalism without engaging with the works of Louis Hartz, Richard Hoftstadter, and C. Vann Woodward among others. 
As to the growing ideological and partisan divide, especially in Congress, this has been the subject of innumerable commentaries and analyses, backed up by statistics showing clear changes in voting patterns and the number of compromises between the parties. Deep concern about this is now being expressed by more pragmatic (not even necessarily "centrist") conservative political commentators like David Brooks. The effect of this on governance is also clear. The only other country in the Western world which experiences anything like the recurrent politically driven budget crises of the USA is Greece - which rather proves my point.

Of course, "pragmatic wheeler-dealing" remains an important part of the US political scene. But if this approach continues to dominate the thinking of the Republican Party in Congress at least, how would Mann explain the fate of ex-speaker John Boehner-a rigid conservative by most people's standards, who was nonetheless rejected by his own party in Congress precisely for trying (to a very limited degree compared to past epochs) to strike deals with the Obama administration? Mann writes of these tendencies as if the Republican Party were some unimportant fringe group - not the party that dominates Congress and stands a good chance of taking the presidency again in 2016.

Wheeling and dealing is indeed a part of every established political system - they would not function otherwise. But given his own work on revolutions, Mann surely knows as well as anyone that even political systems which have in the past proved tremendously successful may decay from a combination of an ossification of their structures and culture and an inability to adapt to meet new challenges. Unless one is an American exceptionalist - and Mann says he is not - there is no reason to believe that the USA must necessarily prove an exception to this rule. Of course, there is good reason to hope that America will in fact be able to adapt successfully to new challenges. But that will require real thought about real change, not a complacent denial of the problems. 